\title{
Evaluation of MDF bonding with polyurethane of castor oil
}

\author{
Caroline Rodrigues Pereira ${ }^{1 *} \mathbb{B}$, Richard Eduard Mölleken' ${ }^{1}$ Felipe Hermenegildo de Souza', \\ Giovanni Schiavinatto Capellari ${ }^{1}$, Salvador Claro Neto ${ }^{2}$ and Elaine Cristina Azevedo ${ }^{1}$
}

*Correspondence:
carolrodrigues.floresta@
gmail.com
${ }^{1}$ Federal University
of Technology-Paraná-UTFPR,
Curitiba, PR, Brazil
Full list of author information
is available at the end of the
article

*Correspondence: carolrodrigues floresta@ of Technology-Paraná-UTFPR, Curitiba, PR, Brazil is available at the end of the article

\begin{abstract}
Adhesives used to bond the wood panels are petroleum-based and has volatile organic compound, VOCs. Harmful substance when inhaled by human being and can cause different problems, such as cancer. As an alternative to replace these adhesives is to use the polyurethane derived from castor oil (PU), a renewable resource that can be used to structural applications, indoor and outdoor environments. It is weather resistant and has good mechanics properties. The aim of this paper is to evaluate the mechanical resistance of glued joint with PU biding MDF panels. It was produced raw MDF samples glued two by two with $0.05 \mathrm{~g}$ of adhesive in $1 \mathrm{~cm}^{2}$. Where 6 samples were used with PVA adhesive, 6 with contact adhesive and 6 with PU. After 72 h it was applied a mechanical analysis technique of shear bond strength, according to the standards ASTM D 3983-93 and ASTM D897-95A. The results shows the shear average resistance of PU was $12.67 \pm 2.26 \mathrm{MPa}$, whereas for the PVA adhesive was $2.55 \pm 0.19 \mathrm{MPa}$ and the contact adhesive was 3.26 $\pm 0.63 \mathrm{MPa}$. It is conclusive the polyurethane derived from castor oil can be used to bind MDF panels, due to its superior shear average resistance compared to PVA and contact adhesives.
\end{abstract}

Keywords: MDF, Polyurethane, Castor oil, Bind

\section{Background}

More than $70 \%$ of wood derivative products use some kind of adhesive, with the increased replacement of wood products by its derivatives generated an increase of synthetic adhesives consume [1].

Normally, the panels binding process to produce furniture is made with thermosetting resins, such as urea-, phenol-, or melamine-formaldehyde and isocyanate [2]. These resins comes from petroleum and has solvent in its compositions, as volatile organic compound, VOC's, toxic, carcinogenic and mutagenic substances [3].

Among the synthetics adhesives, the most used by Brazilian's wood and furniture industry, stand out poly (vinyl acetate) adhesives, PVA, besides the polyurethane ones [1]. The furniture industries use contact adhesives that may provide to its workers leukemia and nasal cancer development risk, apart from instant abortion on women case [4].

These adhesive solvents can be skin absorbed and make it infections susceptible. Also can cause irritations and allergic reaction on sensitive people. When inhaled can cause 
headaches, fatigues, nausea, eyes irritations and in its respiratory systems or mental and visual disorders [5].

The polyurethane derived from castor oil is extract from Ricinus communis and do not have VOC's in its composition [6]. The castor bean (R. communis) is a tropical plant with great oleo chemical potential that can provide polyols from its fatty acids [7]. The castor bean seed's most important constituent is ricinoleic acid, which also is the castor oil biggest component. The hydroxyl groups provide alcohol characteristics to the oil that are relatively stable under different pressure and temperature conditions [8]. Polyurethane can be used in structural applications, as well as indoor and outdoor environments and is weather resistant [9].

Azevedo et al. [10] did a thermo-mechanical characterization polyurethane derived from castor oil by instrumented nanoindentation test and ones concluded that the Berkovich pyramidal tip hardness was $0.14 \mathrm{GPa}$. The modulus of elasticity, with spherical tip, was 2.4 GPa, using Hertz methodology. The viscosity, also measured by spherical tip, was $(22 \pm 2) \times 10^{12} \mathrm{~Pa}$ s. The temperature of initial mass loss was $250{ }^{\circ} \mathrm{C}$ and the glass transition temperature was $76^{\circ} \mathrm{C}$.

Campos and Lahr [11] studied MDF panels, with Eucalyptus and Pinus fibers, resistances properties with 8,10 and $12 \%$ of urea-formaldehyde, polyurethane derived from castor oil bi-component and inorganic resin. The Eucalyptus and Pinus panels with $12 \%$ of PU obtained the best results for both internal adhesion (0.91 and $0.89 \mathrm{MPa})$ and flexion resistance (29.4 and $28 \mathrm{MPa}$ ).

Fiorelli et al. [12] developed sugarcane bagasse panels with polyurethane derived from castor oil and investigated its physical and mechanical characteristics. The results indicate a high-density material and suitable for industrial use.

Silvia et al. [13] evaluated, with European standard EMB/IS-2: 1995 support, the mechanical properties of Pinus fibers panels with polyurethane derived from castor oil (PU) and concluded that with $6 \%$ of PU proportion provided mechanical properties compatible to the standard requirements.

Campos et al. [14] evaluated MDF panels of Pinus caribaea var. hondurensis fibers with polyurethane derived from castor oil, according to the European standards. Its physics and mechanics properties showed superior values than standard's established. With $731 \mathrm{~kg} / \mathrm{m}^{3}, 12 \%$ of thickness swelling and $30.7 \%$ of water absorption, $2754 \mathrm{MPa}$ for MOE and 27.2 MPa for MOR, the internal adhesion was 0.79 MPa. Indicating the adhesive is promising in MDF production.

Substrate adhesion is a physic-chemical phenomenon that provides a tension transfer mechanism between two pieces by molecular process and involves both mechanicals theories of polymer diffusion and chemical adhesion [15]. In these models, a good adhesion requires a good substrate's surface wettability by the adhesive as well as its penetration on the surface pores. Its solidification and its flexibility are also required to reduce the tension effects caused by exertion [16].

The tendency to replace formaldehyde-based adhesives due to its harmful effects in both environment and human health, led the efforts in ecofriendly adhesives research. As PVA, the polyurethane derived from castor oil showed satisfactory results on fiber composites [17] and plywood manufactory [3]. Researches between MDF and polyurethane derived from castor oil interaction are scant, generating a need to study its 
properties. The aim of this paper is to evaluate the mechanical resistance of glued joint with polyurethane derived from castor oil in MDF panels.

\section{Experimental}

It was used the raw MDF panel with $0.70 \mathrm{~g} / \mathrm{cm}^{3}$ of density and $10 \mathrm{~mm}$ of thickness.

The PVA Cascola ${ }^{\circledR}$ Cascorez Extra is PVA-based adhesive, indicated for wooden artifact collage. This adhesive uses the conventional bonding process, once the processes finish within 3-4 $\mathrm{h}$ in room temperature.

The contact Cascola ${ }^{\circledR}$ Extra, according to its manufacturer, is a fast drying adhesive, provides a good finish and high performance [18]. The manufacturer does not provide its technical information.

The polyurethane derived from castor oil was a donated by Cequil Central de Ind. Des. Polímeros de Araraquara-SP is a bi-component of polyurethane resin that acts chemically with wood resin. It is not toxic and is compatible with any kind of wood and its finishing [19]. It has no mineral filler (zero solids content), density of $0.99 \mathrm{~g} / \mathrm{cm}^{3}, 500 \mathrm{cps}$ in $25^{\circ} \mathrm{C}$ of viscosity, total cure time of $72 \mathrm{~h}$ and Shore D hardness of 60 .

\section{Samples}

There were cut 36 pieces from MDF panels, Fig. 1a, in L shapes to adapt to the machine claw. Then, to provide a smooth surface, they were manually sanded with emery paper 220 grit. Then, the adhesive area was marked with a pen, according to the standards ASTM D 3983-93 [20] and ASTM D 897-95A [21], as shown by Fig. 1c.

In the demarked area were added $0.05 \mathrm{~g}$ of adhesive in $1 \mathrm{~cm}^{2}\left(500 \mathrm{~g} / \mathrm{m}^{2}\right)$ in 6 samples for each adhesive, pressing manually about 1 min against another sample provided with

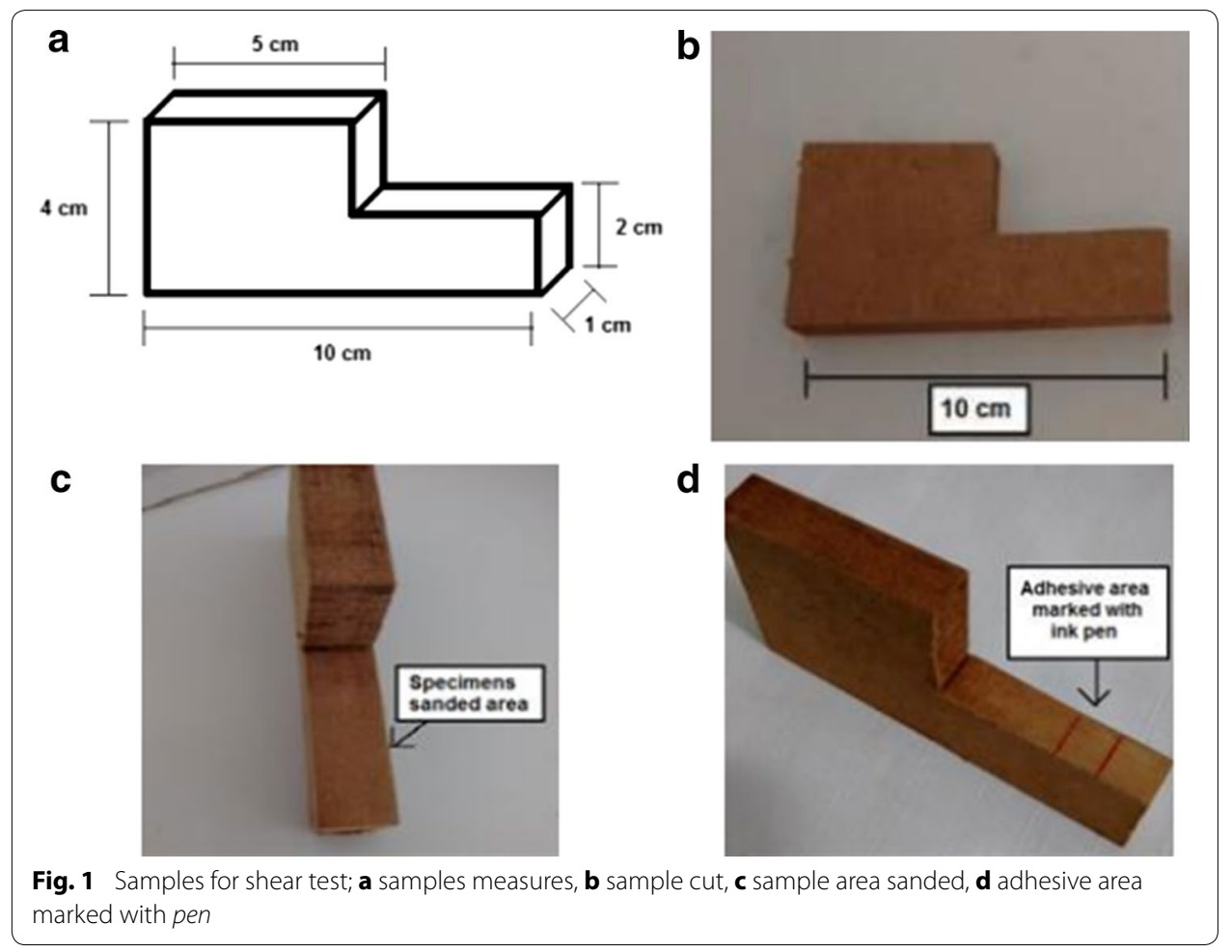


no adhesive, following the manufacturer orientations. The PU manufacturer suggests polyol/pre-polymer proportions of 1:1. After the mixture, the PU was put into a desiccator coupled with pump for $7 \mathrm{~min}$ to remove the air bubbles [19]. The contact adhesive has to be first spread and then wait for 5 min to bind the other piece. PVA adhesive did not require any specific care [18].

After the pressure, it formed 18 samples set in total, which were left at rest for $72 \mathrm{~h}$ in an environment with controlled relative humidity to $50 \%$ and $25{ }^{\circ} \mathrm{C}$ to complete the adhesive drying, Fig. 2. Then, a mechanical analysis technique of shear bond strength was applied.

The shear test was applied according the standards ASTM D 3983-93 [20] and ASTM D 897-95A [21], on an universal test machine, EMIC DL10000, with $500 \mathrm{Kgf}$ of load $2 \mathrm{~mm} / \mathrm{min}$ speed.

\section{Results and discussion}

Figure 3 shows stress-strain curves obtained byshear test.

It can be observed at Fig. 3 the maximum tension obtained by PVA glued joint was $1.5 \mathrm{MPa}$ with $2.5 \mathrm{~mm}$ deformation. The contact adhesive presented $3 \mathrm{MPa}$ and $5.5 \mathrm{~mm}$ deformation. The polyurethane, on the other hand, showed $13.8 \mathrm{MPa}$ and deformation of $7.8 \mathrm{~mm}$

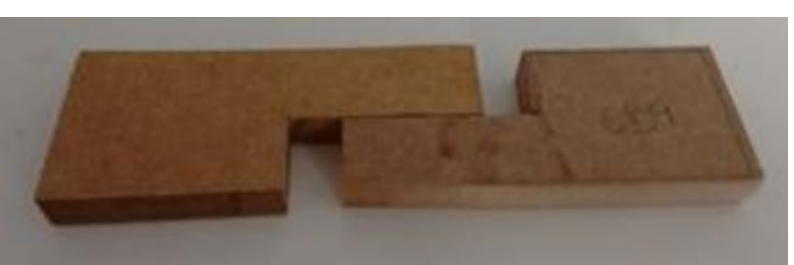

Fig. 2 One set during its rest time

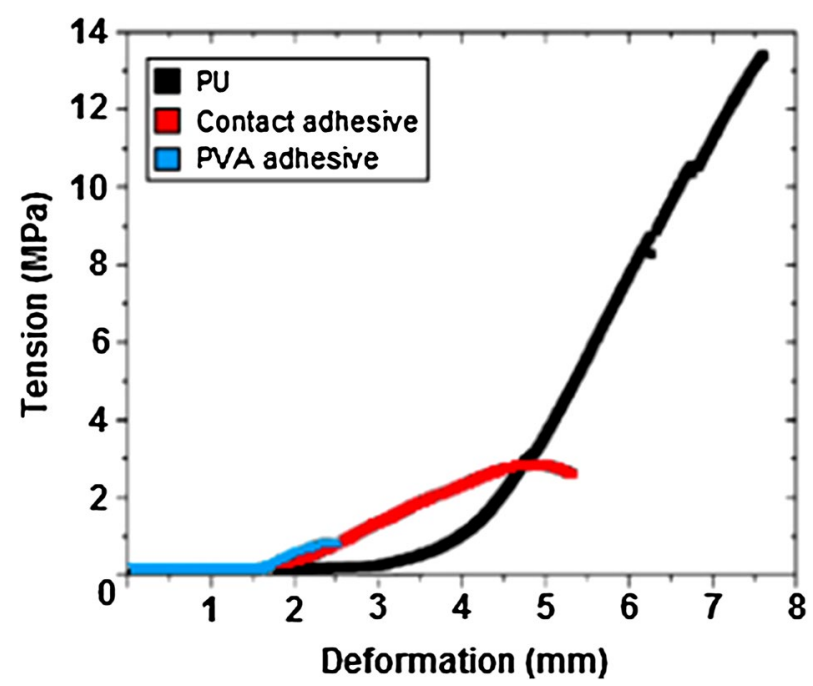

Fig. 3 Stress-strain curves obtained by shear test 
The polyurethane's rupture tensile was superior when compared to others two adhesives, demonstrating its better resistance. Phenol-formaldehyde based adhesives are structural type ones and can be used on outdoor environments. Urea-formaldehyde ones are also structural types but only can be used on indoor environments. On the other hand, polyurethanes are considered a semi-structural adhesive [22] which has limited applications due to its low water resistance when compared to structural ones. Even being a semi-structural adhesive, the polyurethane has better performance than structural ones with external applications.

Figure 4 represent the results obtained by shear test. It can be observed that the PU shear strength is superior to the others adhesive. This can be attributed to polyurethane's strong interaction between free $\mathrm{OH}$ and $\mathrm{NCO}$ groups, that will promote a chemical adhesion among MDF and PU. Merlini et al. [17] claims that this mechanism is responsible for natural fibers surfaces and PU adhesiveness and compatibility.

The shear strength obtained by MDF with polyurethane are superior than others adhesives. Campos et al. [23] tested PVA utilization on Eucalyptus sp. and Pinus sp. plywood production, with $10 \mathrm{~min}$ pressing time and $90{ }^{\circ} \mathrm{C}$. It was found $3.76 \mathrm{MPa}$ for glued joint shear strength.

Campos et al. [24] found, for Pinus sp. plywood panels with polyurethane derived from castor oil with $400 \mathrm{~g} / \mathrm{m}^{2} \mathrm{~g}$ weight, under $1.5 \mathrm{MPa}$ of pressure, $60{ }^{\circ} \mathrm{C}$ for $15 \mathrm{~min}$, statics flexion results for MOR and MOE values 39-56 and 10,000-15,322 MPa, respectively.

A higher wood density may influence veneers adhesive bonds, due to a higher difficulty of adhesive penetration and can create a higher internal steam pressure during the hot pressing. This contributes to reduce the resin-polymerizing rate [9].

The results obtained in this paper approach to its values, being that variations may occur depending the wood species, its gram weight, adhesive type, as well as the environmental conditions to produce the plywood panels. However, it was not found any MDF panels with polyurethane derived from castor oil panel papers to compare the results.

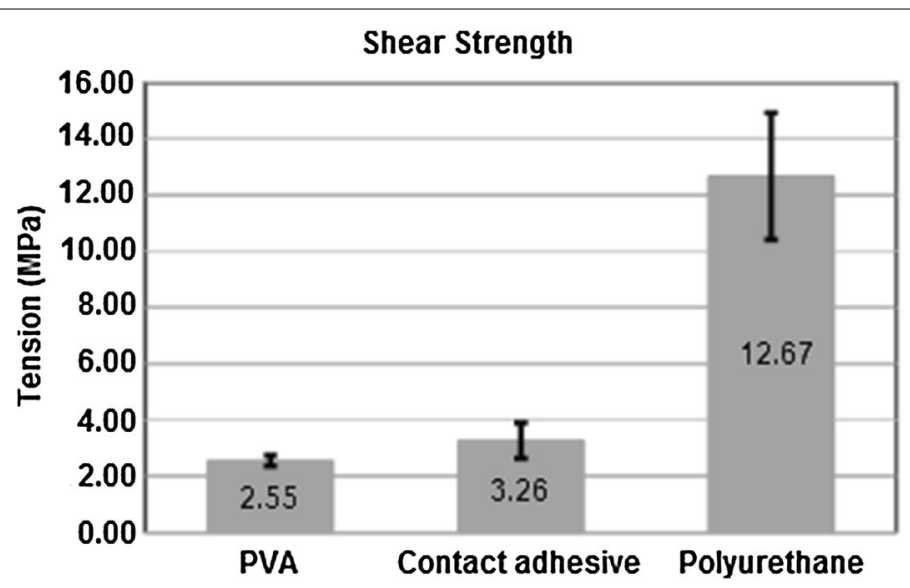

Fig. 4 Average shear strength result for PVA, contact adhesive and polyurethane 


\section{Conclusion}

The results found in this paper show a superior shear strength in MDF with PU samples than PVA and contact adhesives, most commercially used.

Petroleum based adhesives such as PVA and contact adhesive may cause damage to human health and do not come from a renewable resource. This goes against the three sustainability pillars: economically viable, socially fair and ecologically friendly practices. The replacement by furniture industry to green ones is viable, especially because show better bond resistance when compared to traditional adhesives.

With these positives results it may be possible to do deeper studies in this adhesive, such as evaluate the resistance with boiling, dry, cycle and cold water treatments. Also, study its best pressing time, grammar weight and pre-polymer/polyol proportion.

\section{Authors' contributions}

CRP, REM, FHS and GSC participated in performing the experiments and writing of the manuscript, ECA and SCN conceived the study, participating in its design and coordination, helping to drafting the manuscript. All authors read and approved the final manuscript.

\section{Author details}

${ }^{1}$ Federal University of Technology-Paraná-UTFPR, Curitiba, PR, Brazil. ${ }^{2}$ São Carlos Institute of Chemistry-IQSC, USP, São Carlos, SP, Brazil.

\section{Acknowledgements}

The authors express their acknowledgments to the Fundação Araucária, FAPESP, CAPES and CNPq for financial support to the laboratories involved and the company Cequil-SP, for the adhesive donation.

\section{Competing interests}

The authors declare that they have no competing interests.

\section{Liability of note}

The authors are solely responsible for what is contained in this work.

Received: 5 April 2016 Accepted: 29 June 2016

Published online: 08 July 2016

\section{References}

1. de Carneiro ACO, Vital BR, Pimenta AS, Mori FA. Reatividade dos taninos da casca de Eucalyptus grandis para produção de adesivos. Cerne. 2001;7(1):1-9.

2. Correa CA, Fonseca CNP, Neves S, Razzino CA, Hage JE. Compósitos termoplásticos com madeira. Polímeros Ciência e Tecnologia. 2003;13(3):154-65.

3. Wilczak L. Avaliação do comportamento mecânico do adesivo poliuretano derivado de óleo de mamona utilizado na produção de painéis compensados. Trabalho de conclusão de curso-Engenharia de Produção Civil, Universidade Tecnológica Federal do Paraná; 2014.

4. Dahlstrom HV, Erdtmann B, Kvitko K, Rohr P, Silva J. Evaluation of genetic damage in Brazilian footwear-workers: biomarkers of exposure, effect, and susceptibility. Toxicology. 2007;232:235-47.

5. Wegman FR, Tullos TR. Handbook of adhesive bonded structural repair. Adhesion Associates Ledgewood; 1993. p. 232. ISBN-10:0815512937.

6. Marinho NP, Nascimento EM, Nisgoski S, Magalhães WLE, Neto SC, Azevedo EC. Caracterização Física e Térmica de Compósito de Poliuretano Derivado de Óleo de Mamona Associado com Partículas de Bambu. Polímeros Ciência e Tecnologia. 2013;23(2):201-5.

7. Ohara GH, Kojima KE, Rossi JC. Estudo experimental da biocompatibilidade do polímero poliuretano da mamona implantada intra-óssea e intra-articular em coelhos. Acta Ortopédica Brasileira. 1995;3(2):62-8.

8. Silva BBR. Desenvolvimento de adesivos de poliuretano a base de óleo de mamona. Dissertação de mestradoEngenharia de Materiais, Universidade Federal do Rio Grande do Sul; 2006.

9. Iwakiri S. Painéis de madeira reconstituída. Curitiba: FUPEF; 2005; p. 247. ISBN 8590507610.

10. Azevedo EC, Neto SC, Chierice GO, Lepienski CM. Aplicação de indentação instrumentada na caracterização mecânica de poliuretana derivada de óleo de mamona. Polímeros Ciência e Tecnologia. 2009;19(4):336-43.

11. Campos Cl, Lahr, FAR. Propriedades físico-mecânicas de MDF a partir de fibras de madeira de reflorestamento e adesivos alternativos. Tese de doutorado-Engenharia de Materiais, Programa Interunidades, EESC/IFSC/IQSC, Universidade de São Paulo; 2005

12. Fiorelli J, Lahr FAR, Nascimento MF, Savastano H Jr, Rossignolo JA. Painéis de partículas à base de bagaço de cana e resina de mamona_produção e propriedades. Acta Sci Technol. 2011;33(4):401-6.

13. Silva SAM, Christoforo AL, Gonçalves R, Lahr FAR. Strength properties of medium density fiberboards (MDF) manufactured with Pinus elliottii wood and polyurethane resin derived from castor oil. Int J Composit Mater. 2013;3(1):7-14 
14. Campos Cl, Lahr FAR, Christoforo AL, Nascimento MF. Castor oil based polyurethane resin used in the production of medium density fiberboard. Int J Composit Mater. 2014;4(4):185-9.

15. Fourche G. An overview of the basic aspects of polymer adhesion.Part1. Fundamentals. Polym Eng Sci. 1995:35(12):957-67.

16. Reinhart FW, Callomon IG. Survey of adhesion and adhesives. Wade Tech Rep. 1959;1959:58-540.

17. Merlini C, Soldi V, Barra GMO. Influence of fiber surface treatment and length on physico-chemical properties of short random banana fiber-reinforced castor oil polyurethane composites. Polym Test. 2011;30:833-40.

18. Cascola. http://www.cascola.com.br/pt.html. Accessed May 2016.

19. Cequil. Polibond technical manual.

20. American Standards for Testing and Materials, ASTM D3983-93.

21. American Standards for Testing and Materials, ASTM D897-95A.

22. Forest Products Laboratory (FAO). Wood handbook: wood as an engineering material. General Technical Report FPLGTR-190. Madison: United States Department of Agriculture, Forest Service, Forest Products Laboratory; 2010. p. 508.

23. Campos Cl, Ferreira BS, Prates GA, Goveia D, Valentina LVOD. Utilização de adesivo pva em compensados de Pinus sp. e Eucalyptus sp. Braz J Biosyst Eng. 2014;8(1):59-64.

24. Campos Cl, Morais RDV, Nascimento MF. Caracterização físico-mecânica de painéis de madeira compensada produzidos com Pinus sp. e resina poliuretana bi-componente. Revista Madeira Arquitetura Engenharia. 2009:10(24):37-50.

\section{Submit your manuscript to a SpringerOpen ${ }^{\circ}$ journal and benefit from:}

- Convenient online submission

Rigorous peer review

- Immediate publication on acceptance

- Open access: articles freely available online

- High visibility within the field

- Retaining the copyright to your article

Submit your next manuscript at $\boldsymbol{\nabla}$ springeropen.com 